\title{
Undernutrition in lepromatous leprosy, Part II. Altered levels of serum elements. Their association with the disease and not with food deprivation
}

\author{
K N RAO \& K SAHA \\ Department of Allergy and Immunology, Vallabhbhai Patel Chest \\ Institute, University of Delhi, Delhi-110007, India
}

Accepted for publication 22 May 1986

\begin{abstract}
Summary The study found that the diet of lepromatous leprosy patients was not deficient in dietary zinc, copper, calcium and magnesium and this was comparable to that of healthy individuals. However, the serum of these patients showed significantly low levels of zinc, calcium and magnesium but increased copper in comparison to that in healthy control subjects.
\end{abstract}

\section{Introduction}

In an earlier communication, we have reported that mild or moderate undernutrition so often observed in lepromatous leprosy patients was associated with poverty and deprivation of food and not with the disease. ${ }^{1}$ It was also demonstrated that although the calorie intake was the same in both the upper and low economic group of patients as well as healthy controls, the protein, fat and vitamin A consumption were significantly lower in both patient and healthy controls belonging to low economic strata than in those of high socioeconomic groups. Most nutritionists believe that 14 trace elements are essential to control biochemical reactions within the body. ${ }^{2}$ Zinc is involved in protein synthesis and its deficiency has been incriminated to produce progressive thymic involution and impairment of cell-mediated immunity. ${ }^{3}$ Mathur et al. ${ }^{4}$ showed serum zinc deficiency in leprosy patients and treated them successfully with oral zinc therapy. The present study led to a conclusion that the association of low serum levels of zinc, calcium and magnesium as well as increased serum copper levels observed in lepromatous leprosy was related to the disease process. 


\section{Materials and methods}

STUDY AREA, HUMAN MATERIAL, DIAGNOSIS OF LEPROMATOUS LEPROSY AND DIETARY SURVEY

This study was carried out in Singhbhum District, a tribal area of Bihar State, eastern India. The details of study area, human material and classification of them into different economic groups, diagnosis of lepromatous leprosy and dietary survey were described in Part I. ${ }^{1}$

\section{COLLECTION OF SERUM AND ESTIMATION OF TRACE ELEMENTS}

Ten millilitres of fasting blood samples were collected in metal-free tubes from both patients and controls. Sera were separated and stored in plastic vials at $-20^{\circ} \mathrm{C}$ until use. Haemolysed specimens were excluded. Zinc, copper, calcium and magnesium were determined by a Perkin Elmer atomic absorption spectrophotometer, Model No. 2389, by the method described elsewhere. ${ }^{5}$

\section{STATISTICAL ANALYSIS}

The data were grouped according to per capita income, mean and standard deviation (SD) calculated and a statistical significant test (students ' $t$ ') was done.

\section{Results}

The results of the normal subjects and leprosy patients were arranged with respect to per capita income (Table 1). The serum zinc, copper, calcium and magnesium levels in the normal subjects belonging to high and low income groups were comparable. The serum levels of all these elements in lepromatous patients of both high as well as low income groups were also similar (Table 2). However, the mean serum levels of zinc, calcium and magnesium were significantly lower in the patients belonging to both high as well as low income groups than that found in the normal subjects of similar income groups. On the contrary the mean serum copper level in the patients of both high and low income groups was significantly higher than that in the normal subjects belonging to both the income groups (Table 2). These results, therefore, indicated that the observed alteration of the levels of zinc, copper, calcium and magnesium in the sera of lepromatous patients was probably not due to poverty and deficiency of food intake but may be associated with the disease process. In order to substantiate this view, we had analysed the daily dietary intake of these elements in all subjects of both the income groups by the National Institute of Nutrition, Indian Council of Medical Research, Hyderabad, India (Table 3). Tables 2 and 3, when analysed critically 
Table 1. Human material and their number with respect to per capita income

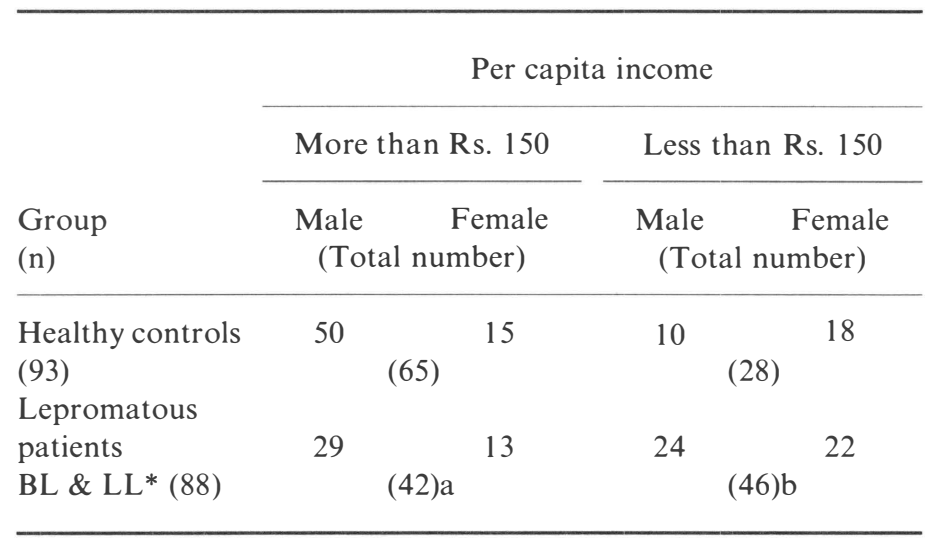

${ }^{*} \mathrm{a}=\mathrm{LL}, 27$ and BL, 19; $\mathrm{b}=\mathrm{LL}, 30$ and BL, 16.

Table 2. Serum levels of zinc, calcium, magnesium and copper in healthy subjects and leprosy patients

Group

Zinc Copper Calcium Magnesium (n) $(\mu \mathrm{g} / \mathrm{dl})$ $(\mathrm{mg} / \mathrm{dl})$

1 Per capita income more than Rs. 150
(a) Healthy controls
$\begin{array}{lll}105 \cdot 8 & 106.6 & 10.93\end{array}$
$2 \cdot 06$
$\pm 22.99 \pm 23.88$
$\pm 1 \cdot 14 \quad \pm 0 \cdot 37$
(b) Lepromatous patients
(BL \& LL)
$68 \cdot 82 \quad 209 \cdot 05$
$7 \cdot 20$
$1 \cdot 53$
(42)
$\pm 10 \cdot 39 \pm 59 \cdot 78 \quad \pm 0 \cdot 11 \quad \pm 0 \cdot 36$

2 Per capita income less than Rs. 150

$\begin{array}{lllll}\text { (c) Healthy controls } & 113.3 & 99.28 & 9.78 & 2.09\end{array}$

(28) $\pm 22.66 \pm 26.86 \pm 1.33 \quad \pm 0.46$

$\begin{array}{llll}\text { (d) Lepromatous patients } \quad 69.48 & 205.08 & 6.92 & 1.44\end{array}$

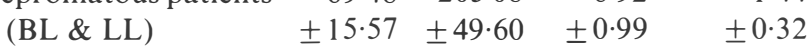

(46)

\begin{tabular}{lcccc}
\hline p value: & & & & \\
a vs b & $0.001^{*}$ & 0.001 & 0.001 & 0.001 \\
c vs d & 0.001 & 0.001 & 0.001 & 0.001 \\
b vs d & NS $\dagger$ & NS & NS & NS \\
\hline
\end{tabular}

* Highly significant. $†$ NS, Not Significant 
Table 3. Association of per capita income with dietary intake and serum levels of zinc and copper in healthy subjects and leprosy patients

\begin{tabular}{|c|c|c|c|c|}
\hline \multirow{2}{*}{$\begin{array}{l}\text { Group } \\
\text { (n) }\end{array}$} & \multicolumn{2}{|c|}{$\begin{array}{l}\text { Per capita income } \\
\text { less than Rs. } 150\end{array}$} & \multicolumn{2}{|c|}{$\begin{array}{l}\text { Per capita income } \\
\text { more than Rs. } 150\end{array}$} \\
\hline & Zinc & Copper & Zinc & Copper \\
\hline \multicolumn{5}{|l|}{$\begin{array}{l}\text { (a) Healthy subjects } \\
\text { (93) }\end{array}$} \\
\hline Dietary intake (g/day) & $6 \cdot 22$ & $1 \cdot 32$ & $10 \cdot 64$ & $2 \cdot 08$ \\
\hline Serum levels $(\mu \mathrm{g} / \mathrm{dl})$ & 113 & 99 & 106 & 106 \\
\hline \multicolumn{5}{|l|}{$\begin{array}{c}\text { (b) Lepromatous patients } \\
\text { (88) }\end{array}$} \\
\hline Dietary intake (g/day) & $5 \cdot 7$ & $1 \cdot 27$ & $9 \cdot 42$ & 1.99 \\
\hline Serum level ( $\mu \mathrm{g} / \mathrm{dl})$ & $69 \cdot 9$ & 205 & $68 \cdot 8$ & 209 \\
\hline
\end{tabular}

Daily recommended intake of zinc and copper are $12.0 \mathrm{mg}$ and $2.50 \mathrm{mg}$, respectively. ${ }^{7}$

showed that the per capita income was associated with the intake of dietary zinc but curiously not with the serum levels of this element. Thus, while the daily intake of zinc in the normal subjects in low income groups was $6.72 \mathrm{mg}$ and their mean serum level was $113 \mu \mathrm{g} / \mathrm{dl}$, the daily zinc intake in the normal subjects belonging to high income group was $10.64 \mathrm{mg}$ and mean serum level was $106 \mu \mathrm{g} /$ dl (Table 3). Furthermore, similar findings were also observed in lepromatous patients. The daily intake of zinc in the low income group was $5.7 \mathrm{mg}$ and the serum level was $69.9 \mu \mathrm{g} / \mathrm{dl}$. On the other hand, the daily intake of zinc was $9.4 \mathrm{mg}$ in patients of the high income group and the serum zinc level was also $68 \cdot 8 \mu \mathrm{g} / \mathrm{dl}$. We therefore conclude that low serum levels of zinc in leprosy patients of both high and low income groups was associated with the illness.

Analysis of daily intake of copper and its serum levels in normal subjects and leprosy patients of both high and low socioeconomic groups led to a similar conclusion as above. Thus the daily copper intake was $2.08 \mathrm{mg}$ in normal subjects and $1.99 \mathrm{mg}$ in lepromatous patients both belonging to the high income group. The difference was not significant. But astonishingly, the mean serum copper level in the latter group, was almost double $(209 \mu \mathrm{g} / \mathrm{dl})$ in comparison to that $(106 \mu \mathrm{g} /$ $\mathrm{dl}$ ) in the normal subjects. A similar observation was also made in the low income group. Daily intake of copper in normal and lepromatous patients was similar, i.e. $1.32 \mathrm{mg}$ and $1.27 \mathrm{mg}$ respectively. But the mean serum copper levels was almost double, $(205 \mu \mathrm{g} / \mathrm{dl})$ in comparison to that in the controls $(99 \mathrm{mg} / \mathrm{dl})$. 


\section{Discussion}

Trace elements catalyse many biochemical reactions in our body, bind with cell membrane, nucleic acids and proteins and are compartmentalized between and within tissues. ${ }^{2}$ Zinc at a concentration of $1.8 \times 10^{4} \mathrm{mn}$ stimulates DNA synthesis in human thymocytes. ${ }^{6}$ Zinc deficiency observed in human undernutrition, produces thymic involution and loss of cell-mediated immunity function. ${ }^{3}$ Mild and moderate malnutrition (protein, vitamin and fat) often seen in leprosy patients may be associated with the observed zinc deficiency. But this possibility was excluded by the results of the present study (Table 3), because in the patients belonging to high income group, though the intake of zinc was comparable to the recommended allowance, ${ }^{7}$ the serum levels were significantly low. The observed decrease in plasma zinc concentration in our patients may not be regarded as a definite evidence of deficiency of zinc in them. However, the zinc deficiency found in our patients might be associated with the impairment of thymus dependent cell-mediated immunity so often found in lepromatous patients.

Hypozincaemia leads to hypercupremia due to zinc-copper antagonism..$^{9}$ Our results showed that the elevated levels of copper were associated with the illness and not with the dietary intake. Another explanation for the observed increase in serum copper level in our patients might be due to the degeneration of muscle caused by mycobacterial invasion and the chronic nature of leprosy and chemotherapy. ${ }^{10}$

Calcium metabolism in leprosy is of particular interest because of bone changes occurring in leprosy. The low serum calcium level in our patients parallel the recent report of Pal et al. ${ }^{11}$ The reduced levels of serum calcium may cause the release of lysosomal enzymes from the polymorphonuclear leucocytes, ${ }^{12}$ infiltrated in the tissues, causing tissue damage.

The observed low serum concentration of zinc, calcium and magnesium might be related to their low absorption from the intestine. This possibility was remote in view of the recent report of normal histological appearance and normal absorptive functions of small bowel in patients of lepromatous leprosy. ${ }^{13}$ This view also gets support from our observed high serum copper levels.

Magnesium is associated with different biological processes in carbohydrate metabolism. Also magnesium and calcium are metabolically interrelated. Hypocalcemia and hypokalemia either individually or together are relatively frequent manifestations of magnesium deficiency in man. Two reasons proposed for the development of hypocalcemia in magnesium deficiency are functional hypoparathyroidism and impaired end organ responsiveness to parathyroid hormone. ${ }^{14}$ The acute effects of calcitonin on bone and kidney also tend to lower serum calcium, magnesium and phosphorus levels. ${ }^{15}$ The present study thus warrants the estimation of serum calcitonin levels in both low and high economic groups of subjects in leprosy spectrum.

This study is helpful in understanding more cogently, the pathogenesis of the disease in relation to biochemical profile and bone involvement. 


\section{Acknowledgment}

The authors are thankful to Singhbhum Navjivan Niketan, Ghatsila and Chief Medical Officer, Hindustan Copper Complex Hospital, Singhbhum, Bihar for their interest in the study. Partial financial assistance from the Indian Council of Medical Research, New Delhi is gratefully acknowledged.

\section{References}

1 Rao KN, Vijay Lakshmi, Kunal Saha. Undernutrition in Lepromatous leprosy, Part I. Is it associated with poverty or with disease? Lepr Rev, 1986; 57: 299-309.

${ }^{2}$ Golden MHN, Golden BE. Trace elements. Potential importance in human nutrition with particular reference to zinc and vanadium. Brit Med Bull, 1981; 37: 31-36.

3 Good R A, West A, Ferandes G. Nutritional modulation of immune responses. Fed Proced, 1980; 39: 3098-3104.

${ }^{4}$ Mathur NK, Sharma M, Mangal HN, Rai SM. Serum zinc levels in sub-types of leprosy. Int $J$ Lepr, 1985; 52: 327-330.

${ }^{5}$ Rao KN, Gupta JD, Sehgal VN, Chakrabarti AK, Saha K. Trace elements in sera of leprosy spectrum. Ind J Lepr, 1985; 556-561.

${ }^{6}$ Nordlind K. Stimulating effect of zinc chloride on DNA synthesis of human thymocytes. Int Arch Allerg appl Immunol, 1985; 77: 461-82.

7 Gopalan C, Ramasastri BV, Balasubramanyam SC. Nutritive value of Indian Foods. National Institute of Nutrition, Indian Council of Medical Research, Hyderabad. 1981.

8 Rea TH. Current concepts in immunology of leprosy. Arch Dermatol, 1977; 113: 345-352.

9 Prasad AS, Brewer GJ, Schoemaker EB, Raebani P. Hypocupremia induced by zinc therapy in adults. J Amer Med Assoc, 1978; 240: 2166-2168.

${ }^{10}$ Leopold IH. Zinc deficiency and visual impairment. Amer J Opthalmol, 1978; 85: 871-875.

11 Pal R, Pal B, Ghosh S. Concentration of serum calcium in leprosy. Lepr India, 1983; 55: 76-79.

12 Wells JV. In Basic and clinical immunology. Fudenberg HH, Stites DP, Caldwell JL, Wells JV (eds), Lange Medical Publication Maruzen Asia Pvt. Ltd, 1980; 191-206.

${ }^{13}$ Kumar N, Malhotra V, Rattan Singh, Vij JC, Anand BS. Structure and function of the small bowel in lepromatous leprosy. Int J lepr, 1982; 50: 148-51.

14 Anast CS, Gardner DW. In Disorders of mineral metabolism. Bronner F, Coburn JW (eds), New York: Academic Press, 1981; 423-506.

${ }^{15}$ Emmersten K. Medullary thyroid carcinoma and calcitonin. Danish Med Bull, 1985; 32: 1-28. 